Volume 12 Number 4, October-December 2018: pp. 298-306. Copyright (c) 2018 FIAT JUSTISIA. Faculty of Law, Lampung University, Bandarlampung, Lampung, Indonesia. ISSN: 1978-5186 | e-ISSN: 2477-6238.

Fiat Justisia is licensed under a Creative Commons Attribution 4.0 International License, which permits unrestricted use, distribution, and reproduction in any medium, provided the original work is

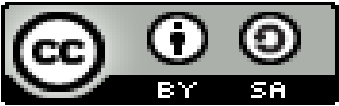
properly cited.

\title{
Archival Management at the University of Lampung
}

\author{
Shandi Patria Airlangga \\ Master Program of University of Lampung, Indonesia \\ patriashandi@gmail.com \\ Teguh \\ University of Saburai, Indonesia \\ teguhfaisal1973@gmail.com \\ Meidiana Ciptasari Ratna Nugraha \\ University of Lampung, Indonesia \\ meidiananugraha@gmail.com
}

\begin{abstract}
Humans as creatures who have limited memories need archives to restore the memories systematically. Archiving has been known since the writing method developed and peoples make records of their archives. Nowadays the archive is valued as a guideline for institutions to make decision. Universities, as the education institutions in carrying out its functions, universities produce archives that comply with the Law No. 43 of 2009 on Archives as the basis for managing archives in universities. The University of Lampung and ANRI have agreed on MoU to work together in applying and disseminating the importance of filing on November 21, 2014. The Rector of University of Lampung Decree No. 4 of 2016 was established on April 20, 2016 regarding the Archive Retention Schedule (JRA), in addition to fulfilling the mandate contained. In Article 48 of Act Number 43 of 2009 concerning the obligation for state universities to have a JRA in archival management, it is also useful as a guide for archival management officials and employees in carrying out their duties. Innovation from ANRI also continued to be socialized to the University of Lampung in realizing efficient archive management.
\end{abstract}

Keywords: Archival, Management, MoU, University of Lampung, ANRI. 
How to cite: Shandi Patria Airlangga, Teguh, and Meidiana Ciptasari Ratna Nugraha, "Archival Management at the University of Lampung", Fiat Justisia, 12 (4), (2018).

DOI: https://doi.org/10.25041/fiatjustisia.v12no4.1371

\section{A. Introduction}

The development of archive management has received special attention from the government with the establishment of legal instruments on archives in Indonesia. Even archival study programs have been opened in universities to produce prospective file managers called archivists. Every state institution is required to manage archives as a center where important documents are collected and empowered.

University of Lampung, as one of the state universities in Indonesia, has collaborated with the National Archives of the Republic of Indonesia (ANRI) which is a state institution specially formed to develop archives. The University of Lampung and ANRI have agreed on an MoU to work together in applying and socializing the importance of archiving. This agreement began on November 21, 2014, during the Rector of University of Lampung Sugeng P. Harianto with the Head of ANRI Mustari Irawan. The purpose of this MoU is to save and empower the archives within the scope of state universities, namely the University of Lampung according to the mandate of Law Number 43 of 2009 concerning Archives.

To socialize archival management, it takes time and periodic archival trainings that continue to be carried out by the University of Lampung on its staff. Until now, the development of archives at the faculty level has not been maximized, but it has gone well. Innovations in the field of archives continue to be socialized by ANRI, even in 2018 several workshops have been held on sending letters via the internet. This method was developed to make time and energy of letter officer assigned more efficient to send letters.

In this digital era, technology continues to be developed and become a homework for the government to be able to keep up with globalization and the times. State documents have a very important power in maintaining the integrity of the nation. Very dangerous if the original documents of the country until damaged, lost, and even falsified. Then the role of the archive is very important as a memory center and recording historical events, as well as legality and authentic evidence in the event of a problem. For this reason, this paper will discuss archival management at University of Lampung and its regulations.

\section{B. Methods}


This research was carried out empirically based on the experience of writers who work in the field of archival management at the Faculty of Law, University of Lampung and had several archival training. The consequences and implications of the stipulation of legal instruments on archives will also be discussed comprehensively. Data were analyzed qualitatively by describing systematically so that the substance of this study could be clearly understood.

\section{Results and Discussion}

\section{The Importance of Archives for Human Life}

Sir Hirary Jenkison argues that archives are all letters and copies that have been used in an office. T.R. Schellenberg said the archives of a government or private are valuable things to be preserved in order to find research stored in an archival institution. Mr. S. Muller, Mr. J.A. Feith and Mr. R. Fruin interpreted the archive as a whole written document. Furthermore Heinrich August Erhard argued that the archive was a collection of administrative activities that had been done, then stored for historical purposes as written evidence. Margaret Odell and Earl Strong said the archives are written facts and are known about the events of an organization. William Benedon interpreted the archive as a paper, book, photo, short film, map, painting, chart, card, magnetic tape, or mold that had been created by a company and had been used by the company as evidence of its activities, also because there was information contained in it. ${ }^{1}$

The history of archives actually began when the writing method was known. With written methods or traditions, people began to write notes about their activities both in order to carry out their functions in work and for personal. These records are then recognized together as proof of transactions between parties who have interests, then stored as records. The evidence of the transaction regulates the ties of the transaction actors or can be said to form a legal bond. Departing from this understanding, the archive continues to experience development both in terms of the type of media, format, function and management system.

In the development of the world, each nation has its own archival history, along with the growth of written traditions that developed in its ethnic and cultural environment. Of the various travel archives of the nations in the world only a small portion is recorded in the history of civilization. ${ }^{2}$ The archive is currently a tool in making decisions for leaders in determining their steps. Archives that are authentic evidence are managed by archival

\footnotetext{
${ }^{1}$ Nandang Alamsah Deliarnoor, "Pengantar Aspek Hukum dalam Kearsipan”, Universitas Terbuka Repository: ASIP4202/MODUL 1, (2016), pp. 6-7.

2 Syauki Hadiwardoyo, "Manajemen Kearsipan di Indonesia", Universitas Terbuka Repository: ASIP4102/MODUL 1, (2014), p. 1.
} 
procedures so that they are appropriate and appropriate services when needed, also in the event of an event that is outside of human will, such as loss and damage to archives due to natural disasters. ${ }^{3}$

Humans are creatures that digest and create information. Information created by humans can be grouped into 2 , namely recorded and unrecorded information. the media can be manual/textual, graphic, electronic, and audiovisual. The recorded information is known as the archive. Some reasons why humans keep their archives, namely for economic, social, legal, privacy, and other reasons. Documents have legal value, namely those relating to documents that are useful as a basis for the government to protect the rights and serve the community, for example land certificates. There are many other documents that also have administrative and informative value. ${ }^{4}$

Archives are primary documents that have characteristics as original information from first hand and record of an event. Archives have an important role as a center of memory, information sources, monitoring tools, policy formulation and decision making within an organization. Archives that do not have a use value when stored will result in a buildup of archives. As a result there needs to be more space so there will be no buildup. Therefore, as a solution that can overcome the problem of archives is by doing depreciation or stream of archives. ${ }^{5}$

Archival management functions to maintain archival balance in terms of creation, document traffic, recording, forwarding, distribution, use, storage, maintenance, transfer and destruction. The purpose is to simplify the type and volume of archives and to utilize their use for enhancing business professionalism with the smallest expenditure. The archive is divided into two types, namely dynamic archive and static archive. Dynamic archive is archive that are used directly in the administration of state administration. Static archive is archive that are not used directly for the daily administration of state administration. ${ }^{6}$ Apart from all that, the goal of archival activities for a country should be to ensure the safety of national accountability materials about planning, implementing, and organizing national life and to provide accountability for government activities. ${ }^{7}$

\section{Regulations for Archival Management in Universities}

\footnotetext{
3 Verry Mardiyanto, "Strategi Kegiatan Preservasi Arsip Terdampak Bencana", Khazanah, Jurnal Pengembangan Kearsipan, 10 (2), (2017), p. 93.

${ }^{4}$ Setiawan, David, and Triono D. Hakim. "Manajemen Arsip Perguruan Tinggi Sebuah Analisa Swot", INA-Rxiv, (2018), p. 879.

${ }^{5}$ Nabila Azzahra, "Penyusutan Dokumen Perusahaan di PT. Kereta Api Indonesia (Persero)", Khazanah, Jurnal Pengembangan Kearsipan, 10 (2), (2017), p. 108.

${ }^{6}$ Zulkifli Amsyah, Manajemen Kearsipan, Jakarta: Gramedia Pustaka Utama), (2003), p. 2.

${ }^{7}$ Gita Dwi Noviani, "Pengelolaan dan Penjaminan Keamanan Arsip Vital", Minithesis Syarif Hidayatullah State Islamic University Jakarta, (2018), p. 11.
} 
Universities in Indonesia as scientific institutions play a strategic role in the development of an intellectual nation's civilization, because there are 3 main functions known as the Tri Dharma of Higher Education, namely education, research, and community service. In carrying out its function, the college produces records of information or archives which are records of valuable events for universities and at the same time public assets that need to be managed properly as authentic evidence and accountability for university performance that reflects the achievements of the Higher Education Tri Dharma. Therefore, archives created by universities are very important in the implementation of life in society, nation and state. Article 27 of Law Number 43 on 2009 of Archives $^{8}$ become the basis for archival management in universities.

Law Number 43 of 2009 and Government Regulation Number 28 on 2012 of Implementation of Law Number 43 on 2009 of Archives ${ }^{9}$, has to become to a pillar in the implementation of national archives so that many things need to be prepared to realize the purpose of archiving. ${ }^{10}$ Article 48 of Law Number 43 on 2009 explicitly requires every state institution, regional government, state university, and BUMN, as well as BUMD to make/have an archival guideline called the Archive Retention Schedule (JRA). In this article, only state universities are required to have an archival management unit, while private universities are not yet required.

Article 1 number 2 of Law No. 43 on 2009 regulates that the archive is a record of activities and events in various forms and media in accordance with the development of information and communication technology created and accepted by state institutions, regional governments, educational institutions, companies, political organizations, community organizations, and individuals in the implementation of community life, nation and state. ${ }^{11}$ Regulation of the Head of ANRI Number 24 of 2011 concerning Guidelines for Organizing Archives in the Universities Environment and the Head of

\footnotetext{
${ }^{8}$ Law Number 43 on 2009 of the concerning Archival, (State Gazette of 2009 Number 152, State Gazette Number 5071).

${ }^{9}$ Government Regulations Number 28 on 2012 of concerning Implementation of Law Number 43 of 2009 on the concerning Archives, (State Gazette of 2012 Number 52, State Gazette Number 5286).

${ }^{10}$ Bambang P. Widodo, "Kedudukan Arsiparis dalam Melakukan Penelitian, Pengkajian dan Pengembangan Sistem Kearsipan”, Khazanah, Jurnal Pengembangan Kearsipan, 10 (2), (2017), p. 76.

${ }^{11}$ Yohanna.Y.R. Watofa, "Implementasi Sistim Kearsipan di Indonesia", Legal Pluralism, 2 (2), (2012), p. 225.
} 
ANRI Regulation Number 14 of 2014 concerning ANRI Work Organization ${ }^{12}$ also becomes the legal basis for archival management in universities. ${ }^{13}$

Archival organization is a work unit in an institution whose function and task is to manage records. Archival organizations consist of processing units, archival units, and archival agencies. The Processing Unit is a work unit in the archive creator who has the task and responsibility to process all records relating to the creation of archives in his environment. The processing unit is called a central file. In carrying out its duties, the processing unit is tasked with managing active dynamic archives.

The Archival Unit is a work unit on the archive creator who has the duty and responsibility to manage the inactive archive. The archive unit is referred to as the archive center or record center. The function of the establishment of the archive center is to streamline the number of institutional archives, making it easier for processing units to manage the archives, manage archives according to their status, with the optimal use of archives, the decisions taken by the leaders of an institution are also more targeted whereas The Archival Agencies is an organizational unit in charge of managing static archive. ${ }^{14}$

\section{Development of Archival Management at the University of Lampung}

The establishment of the Archival UPT of the University of Lampung was determined based on the Republic of Indonesia Ministry of Education and Culture Regulation Number 72 on 2014 on August 7, 2014, concerning the Organization and Work Procedure of the University of Lampung. The Technical Implementation Unit in the field of records management is led by a Head of Archival UPT which coordinates directly with the Vice Rector for General and Financial Affairs. The main task is to carry out the management and storage of archives. In addition, the UPT Archives carry out the following functions:

a. Develop plans, programs and budgets of the UPT;

b. Empowerment and archive management; and

c. Implementation of UPT administration.

Meanwhile, Coordinator the UPT Archives Administration has the task of planning, finance, staffing, management, administration, domesticity and management of state property. The administrative officer, led by a Head of the UPT who was in charge of the Vice Rector for General and Financial

\footnotetext{
${ }^{12}$ Head of ANRI Regulation Number 24 on 2014 of the concerning ANRI Work Organization.

${ }^{13}$ Head of ANRI Regulation Number 24 on 2011 of the concerning Guidelines for Organizing Archives in Higher Education Environments.

${ }^{14}$ Herman Setyawan, "Pemanfaatan Sistem Informasi Kearsipan Statis untuk Menunjang Pelayanan di Arsip Universitas Gajah Mada", Minithesis Yogyakarta: Yogyakarta State University, (2013), pp. 9-10.
} 
Affairs. ${ }^{15}$ With the issuance of the University of Lampung Rector Regulation Number 4 of 2016 on April 20, 2016, concerning Archive Retention Schedule $(\text { JRA })^{16}$ approved by the Head of ANRI based on letter No. BPK.03.09/51/2015 on December 4, 2015, concerning the JRA Agreement of the University of Lampung, in addition to fulfilling the mandate contained in Article 48 of Law Number 43 of 2009 concerning the obligation of archive management for state universities to has a JRA, as well as work guidelines for archival management officials and employees.

The archival organizational structure at the University of Lampung consists of Archival Unit 1 located in the Rectorate Building, which is tasked with integrating archives from all faculties and other structural institutions in the University of Lampung, namely the Archives Unit 2. Innovations from ANRI also continue to be socialized to the University of Lampung, one of which is about a Dynamic Archival Information System (SIKD), where the archival system will use a SIKD application that is operated by a computer and the internet to send letters and archive in time efficient as well as letter registering staff and archive managers.

\section{Conclusion}

The archive is an event record that has a form and is applied to a written or digital media. Archives are very useful for social and state life. The role of the archive is very important in its function as authentic evidence in the event of a problem. Law Number 43 of 2009 concerning archives requires state universities to manage their archives as accountability to the government in the field of education. Archive management at the University of Lampung has run well even though it is still not optimal. Innovations from ANRI continue to be socialized at the University of Lampung to develop and streamline the performance of archival management and employee officials.

${ }^{15}$ UPT Archival University of Lampung, http://arsip.unila.ac.id/profil/sejarah, accesed on September 22th, 2018.

${ }^{16}$ Rector of University of Lampung Regulation Number 4 on 2016 of the concerning Archive Retention Schedule (JRA). 


\section{A. Book}

\section{Bibliography}

Amsyah, Zulkifli. (2003). Manajemen Kearsipan. Jakarta: Gramedia Pustaka Utama.

\section{B. Journals and Article}

Bambang P. Widodo, "Kedudukan Arsiparis dalam Melakukan Penelitian, Pengkajian dan Pengembangan Sistem Kearsipan", Khazanah, Jurnal Pengembangan Kearsipan, 10 (2), (2017), https://doi.org/10.22146/khazanah.30080

Gita Dwi Noviani, "Pengelolaan dan Penjaminan Keamanan Arsip Vital", Minithesis Syarif Hidayatullah State Islamic University Jakarta, (2018) Herman Setyawan, "Pemanfaatan Sistem Informasi Kearsipan Statis untuk Menunjang Pelayanan di Arsip Universitas Gajah Mada", Minithesis, Yogyakarta State University, (2013)

Nabila Azzahra, "Penyusutan Dokumen Perusahaan di PT. Kereta Api Indonesia (Persero)", Khazanah, Jurnal Pengembangan Kearsipan, 10 (2), (2017), https://doi.org/10.22146/khazanah.30083

Nandang Alamsah Deliarnoor, "Pengantar Aspek Hukum dalam Kearsipan", Universitas Terbuka Repository: ASIP4202/MODUL 1, (2016),

Setiawan, et al, "Manajemen Arsip Perguruan Tinggi Sebuah Analisa Swot", INA-Rxiv, (2018), https://doi.org/10.31227/osf.io/2cz8x

Syauki Hadiwardoyo, "Manajemen Kearsipan di Indonesia", in the Universitas Terbuka Repository: ASIP4102/MODUL 1, (2014), p. 1.

Verry Mardiyanto, "Strategi Kegiatan Preservasi Arsip Terdampak Bencana", Khazanah, Jurnal Pengembangan Kearsipan, 10 (2), (2017), https://doi.org/10.22146/khazanah.30081

Yohanna.Y.R. Watofa, "Implementasi Sistim Kearsipan di Indonesia", Legal Pluralism, 2 (2), (2012), 225.

\section{Legislations}

Law Number 43 on 2009 of the concerning Archival.

Government Regulations Number 28 on 2012 of the concerning Implementation of Law Number 43 on 2009 of the concerning Archives.

Head of ANRI Regulation Number 24 on 2011 of the concerning Guidelines for Organizing Archives in Higher Education Environments.

Head of ANRI Regulation Number 24 on 2014 of the concerning ANRI Work Organization.

Rector of University of Lampung Regulation Number 4 on 2016 of the concerning Archive Retention Schedule (JRA). 


\section{World Wide Web}

UPT Archival University of Lampung, http://arsip.unila.ac.id/profil/sejarah, accessed on September 22nd, 2018. 